\title{
Analysis of meteorological drought in Sokoto State for the past four decades (1970-2009)
}

\author{
Mansur Bello Dogondaji, Aishat Muhammed \\ Department of Geography, Shehu Shagari Colleges of Education, Sokoto, Nigeria
}

\begin{abstract}
Meteorological drought disaster is a serious problem in the Sahelian region of the world. This strongly affects the hydrology of the region and creates severe constraint to agriculture and water management. This paper therefore, examines the rainfall characteristics and the extent of meteorological drought in Sokoto state, Nigeria. Daily rainfall data were obtained for a period of four decades (1970-2009) from Nigerian Meteorological Agency (NIMET) through Sultan Abubakar III International Airport, Sokoto Synoptic Station. Data collected were analysed using statistical techniques. The result of the descriptive statistics varies from year to year and slight increase of mean monthly rainfall was observed. Standardized Precipitation Index (SPI) and Rainfall Anomaly Index (RAI) were used in classifying drought severity into severe, moderate and mild conditions. The result is already anticipated since Sokoto State lies within the Sudano-Sahelian region that generally known to be draught prone. Recommendations were offered based on the outcome of the result.
\end{abstract}

Keyword: Meteorological Drought; SP1; RA1; ITD Model; Sokoto State

\section{INTRODUCTION}

A major evidence of global climatic anomaly drought, it is a climatic phenomenon peculiar to the African continent, especially in the Sudano-Sahelian region and northern part of Nigeria where Sokoto State is located (Fidelis, 2003). Drought is universally acknowledged as a phenomenon associated with scarcity of water that has significant impact on the human environment, consequently, worsening the nation's economic structure (Bruins $\&$ Berliner, 2004). It varies with regards to time of occurrence, duration and extent of the area affected. It is broadly classified into four categories, namely: meteorological, hydrological, agricultural and socio-economic drought.

\section{Concept of Drought}

There is no universally acceptable definition of drought. Therefore, definitions have been classified as conceptual and operational. Operational definition on the one hand is crucial because it attempts to determine the onset, severity, spatial distribution and cessation of drought condition. On the other hand, conceptual definition of drought is also very important because it helps people to understand the concept (Gonzalez, et-al 2001). According to Fidelis (2003), drought is a protracted period of deficiency in precipitation which causes extensive damage to crops and loss of agricultural produce. On the other hand, 
it is an insidious hazard of nature that originated from a deficiency of precipitation over an extended period of time, usually a season or more.

This deficiency results in a water shortage for human activities and the functioning of physical environment. In general, drought gives an impression of water scarcity due to insufficient precipitation, high evapo-transpiration and over-exploitation of water resources or combination of these parameters.

Drought has three distinguishing features which include: intensity, duration and spatial coverage. Intensity refers to the degree of the precipitation shortfall and severity impacts associated with the shortfall. Duration considers the temporal pattern, while spatial features involve the affected areas (WMO, 2006).

The dynamic character of drought challenges the ability of planning and effort at providing relief to affected areas. It has been estimated that drought result in annual economic losses of about 86-88 billion dollars in the United States (Jesslyn et-al, 2002).

\section{Types of Drought}

As has been said earlier, drought can be categorized into four, namely: meteorological, hydrological, agricultural and socio-economic.

\section{Meteorological Drought}

Meteorological drought is defined as the extent of precipitation departure from normal in comparison with long average and duration of the dry period (Smakhtin and Hughes, 2004). Definition of drought should be considered from one region to another, this is because, the atmospheric conditions that result in deficiencies of precipitation are highly variable from one region to another (Fidelis, 2003). Basically, there are numerous indices which are used for meteorological drought quantification.

These integrate various hydro-meteorological parameters obtained from data series of rainfall, stream flow, evaporation and other water deficiency indicators (Otun and Adewumi, 2009). The most commonly used meteorological drought indices are: Palmer Drought severity Index (PDSI), Bhalme and Mooley Drought Severity Index (BMDI), Rainfall Anomaly Index (RAI), Reclamation Drought Index (RDI), Surface Water Supply Index (SWSI) and Standardized Precipitation Index (SPI).

However, there are other indices for quantifying metrological drought in a place over a period of time. These are: Onset of Rainy Season (ORS) defined as the first day it rains in a season; Cessation of Rainy Season (CRS) defined as the last day it rains in season.

Bhalme and Mooley (1980), defined onset as the beginning of rainy season which accumulates at least 20 minutes of rainfall in 3 days after $1^{\text {st }}$ May; while cessation of the rainy season is considered as 20 successive days without rain after the $1^{\text {st }}$ September of a year.

Other indices are: length of rainy season which is defined as the difference between CRS and ORS (LRS), total wet days, defined as the total number of days it rains within a season (TWD), total number of dry days which is the number of days without rain within the whole season (TDY), length of dry season (LDS), maximum dry spell length within a wet season (MDL) and mean seasonal rainfall depth (MAR) (Otun and Adewumi, 2009).

\section{Hydrological Drought}

This is defined in terms of the departure of surface and subsurface water supplies for some average conditions at various points in time (Sinha-Ray, 2002). Surface and subsurface 
water supplies include: Stream levels, ground water, aquifers, stream flow, reservoirs and lakes. They are often used for multiple purposes such as flood control, irrigation, recreation, navigation, hydroelectric power generation and wildlife habitat. Competition for water in these storage systems increases significantly during hydrological drought.

\section{Agricultural Drought}

This refers to situations in which the moisture in the soil is no longer sufficient to meet the crop growing in an area. Soils also vary in their water characteristics. For example, soil having a high water holding capacity soils are prone to drought (Smakhtin and Hughes, 2004). Agricultural drought is interrelated with meteorological and hydrological drought, through storage of precipitation, difference between actual and potential evapo-transpiration, soil water deficits and reduction of ground water reservoir level.

\section{Socio-Economic Drought}

Socio-Economic drought refers to the situation where water shortages affect people's lives. This type of drought differs from other types of drought because it associated human activities with element of meteorological, hydrological and agricultural drought (ISOR, 2003).

\section{Conceptual Framework}

The Inter-tropical Discontinuity (ITD) services as the conceptual framework for this paper. It is the boundary zone separating the air masses from the northern and southern hemisphere respectively which is neither frontal nor always convergent.

These air masses include the tropical continental air mass which is dry, dust and blows from Sahara desert, while the tropical maritime air mass which is dry, humid and moisture laden is blowing from Atlantic-ocean.

The ITD assumes its northern most position around latitude $20^{\circ} \mathrm{N}$ in August, and this marks the height of the rainy season in west Africa; in January, the ITD attains its southern most position around latitude $6^{\circ} \mathrm{N}$ and this marks the peak of the dry season in west Africa with the exception of the coastal areas. According to Adekunle (2004), seasonal distribution, type of rainfall and length of the rainy season as well as the general weather conditions experienced in the course of the year at a given location in West African region depends primarily on the location relative to the position of ITD and associated weather zones.

\section{Study Area}

Sokoto state was created and separated from Niger State in 1976. Geographically it is located within Sudan Savannah Zone on latitudes $13^{\circ} 35^{\prime} \mathrm{N}$ to $14^{\circ} 0^{\prime} \mathrm{N}$ and on longitudes $4^{\circ} \mathrm{E}$ to $6^{\circ} 40^{1} \mathrm{E}$. It has a total population of 3,702,676 million (NPC 2006). Sokoto State shares borders with Niger Republic to the North, Kebbi State to the West and South and Zamfara State to the East.

\section{MATERIALS AND METHODS}

This paper heavily relies on the rainfall data for the period of forty-years (1970-2009) collected from the Nigerian Meteorological Agency (NIMET) via Sultan Abubakar III 
International Airport Synoptic Station. The collection of fourty-years rainfall data was based on the World Meteorological Organization (WMO) standard so as to allow for the calculation of climatic normal whether of temperature or of precipitation (Ayoade, 2004).

\section{1. Methods of Data Analysis}

\section{Time Series Analysis (TSA)}

The mean monthly was estimated by dividing the accumulated rainfall for a month by the total number of days in rains it that month using mean equation. The data were input into Microsoft Excel and transposed to make a sum of 480 months (40 years). The analysis was carried out using Minitab software.

\section{Co-efficient of Variation}

The inter-annual and inter-decadal variability of rainfall in Sokoto state over the period (1970-2009) were examined using the co-efficient of variations. It is expressed mathematically as follows:

$$
\mathrm{CV}=\frac{\bar{\sigma}}{\overline{\mathrm{x}}}
$$

where: $\mathrm{CV}=$ Co-efficient of Variation

$\bar{\sigma}=$ Standard deviation

$\overline{\mathrm{x}}=$ Mean of the Time series

\section{Walter's (1967) technique}

This formula or technique is used in the determination of onset and cessation dates of the rains as well as the length of the growing season. The computations were based on the following formula:

Days in Month X (51-accumulated rainfall in previous month)

\section{Total rainfall for the month}

where the month under reference is that particular month in which the accumulated total of rainfall is in excess of $51 \mathrm{~mm}$. For computing the cessation date, the formula above is applied in the reverse order by accumulating the totals backward from December.

\section{Dry Spells Analysis}

The analysis was carried out using daily rainfall data from 1970-2009. Five consecutive days with rainfall below $2.5 \mathrm{~mm}$ proposed by Chowdhury (1978) within the growing season were used in determining the frequency of dry spells that is between $7^{\text {th }}$ May to $30^{\text {th }}$ September.

\section{Standardized Precipitation (SPI)}

SPI is an Index based on precipitation record for a location and the chosen periods are usually months or years. 12 months time scale was considered. This is because of the discrete 
nature of rainfall in semi arid environment. SPI for a particular station as determined using the following equation:

$$
\begin{aligned}
& \text { SPI }=\left(X_{i k}-X_{i} 1 \sigma_{i}\right) \\
& \text { where: } \\
& \text { SPI = Standardized Precipitation Index } \\
& X_{\mathrm{ik}}=\text { Rainfall observed for the station } \\
& X_{\mathrm{i}} \quad=\text { Mean rainfall recorded for the station } \\
& \sigma \quad=\text { Standard deviation for the station }
\end{aligned}
$$

All negative SPI values indicate the occurrence of drought while positive values show no drought (Akeh et al, 2000).

\section{Rainfall Anomaly Index (RAI)}

In this technique, the precipitation values for the period of study were ranked in the descending order of magnitude with the highest precipitation being ranked first and the lowest precipitation being ranked last. The average of the ten highest precipitation values as well as that of the ten lowest precipitation values for the period of the study was calculated. The first average is called the maximal average of 10 extrema and the second average is called the minimal average of 10 extrema. They are known as average precipitation of 10 extrema for positive and negative anomalies respectively. This technique which was developed by Rooy-van (1965) is given by the following equations:

$$
\mathrm{RAI}= \pm 3 \quad \frac{\underline{\mathrm{P}}-\overline{\mathrm{P}}}{\mathrm{E}-\mathrm{P}}
$$

Where:

RAI = Rainfall Anomaly Index

$\overline{\mathrm{P}} \quad=$ Long-term average of the annual rainfall $(\mathrm{mm})$

$\overline{\mathrm{E}}=$ Average precipitation of $10-$ Extrema $(\mathrm{mm})$ for both positive and negative anomalies

$\mathrm{P} \quad=$ Actual rainfall for each year

$\pm 3 \quad=$ Constant.

\section{Spatial Analysis of Drought}

The analysis of spatial occurrences of drought were carried out using recent series data from $(2000-2009)$. The analysis was carried out using Arc Gis map software.

\section{RESULT AND DISCUSSION}

\section{Trend in Mean Monthly Rainfall in Sokoto (1970 - 2009)}

The result of the mean monthly rainfall for 40 years $(1970-2000)$ in Sokoto State was subjected to time series analysis. The result shows slight level of variation especially in the mean monthly rainfall. It also indicates that Mean Absolute Percentage Error (MAPE) is 181. 173, Mean Absolute Deviation (MAD) is 6.706 and the Mean Square Deviation (MSD) is 63.015. The MAPE, MAD, and MSD values measure the accuracy level for the time series. The trend line equation is presented as follows: 
Linear trend equation $=\mathrm{Yt}=5.14675+4.40 \mathrm{E}-30 * \mathrm{t}$

The above equation implies that slight increase has been recorded in monthly values of rainfall in the period under study. Thus, the mean monthly rainfall in Sokoto suggests that the rainfall has been increasing on monthly basis through out the rainy season. Indeed, the equation shows that for every $5.1 \mathrm{~mm}$ monthly mean in Sokoto, rainfall will increase by $0.0044 \mathrm{~mm}$. The trend suggests an increase in rainfall in the near future, which is an evidence of climate change as predicted by NIMET (2011).

\section{Inter-Annual Variability of Rainfall in Sokoto State}

Table 1. below which contains the data on the pattern of Annual Rainfall departure from normal shows the result of the annual rainfall for four decades $(1970-2009)$ and the long term mean calculated as $600.06 \mathrm{~mm}$. The analysis shows high level of inter-annual variability from year to year with the highest amount in $1998(844.1 \mathrm{~mm})$ and 1977 (342.8 $\mathrm{mm}$ ) which were characterized as meteorological drought periods of $40 \%$ below the long term mean and $43 \%$ below the mean value. This is related to Sinha-Ray (2000) definition of meteorological drought as stated earlier. The co-efficient of variation indicates high level of variability with the highest inter-annual variability in $1970(218 \%)$ and the lowest in 1985 with $0.71 \%$. the result also reveals that the standard deviation was highly variable from 1970 $-2009$.

Table 1. Pattern of Annual Rainfall Departure from Normal in Sokoto State (1970 - 2009).

\begin{tabular}{|c|c|c|}
\hline Years & $\begin{array}{c}\text { Annual Rainfall. } \\
\text { (mm) }\end{array}$ & Deviation \\
\hline 1970 & 625.7 & +25.64 \\
\hline 1971 & 342.8 & -257.3 \\
\hline 1972 & 534.1 & -65.96 \\
\hline 1973 & 330.2 & -269.9 \\
\hline 1974 & 479.7 & -120.4 \\
\hline 1975 & 542.2 & -57.86 \\
\hline 1976 & 674.7 & +74.64 \\
\hline 1977 & 836.0 & +235.9 \\
\hline 1978 & 711.7 & +111.6 \\
\hline 1979 & 594.9 & -5.160 \\
\hline 1980 & 549.9 & -50.16 \\
\hline 1981 & 560.3 & -39.76 \\
\hline 1982 & 565.9 & -34.16 \\
\hline 1983 & 623.2 & +23.14 \\
\hline 1984 & 439.0 & -161.1 \\
\hline
\end{tabular}




\begin{tabular}{|c|c|c|}
\hline 1985 & 434.8 & -165.3 \\
\hline 1986 & 475.8 & -124.3 \\
\hline 1987 & 369.4 & -230.7 \\
\hline 1988 & 667.3 & +67.24 \\
\hline 1989 & 478.4 & -121.7 \\
\hline 1990 & 653.9 & +53.84 \\
\hline 1991 & 708.8 & +108.7 \\
\hline 1992 & 549.0 & -51.06 \\
\hline 1993 & 642.2 & +42.14 \\
\hline 1994 & 762.1 & +162.0 \\
\hline 1995 & 508.3 & -91.76 \\
\hline 1996 & 641.0 & +40.94 \\
\hline 1997 & 645.5 & +45.44 \\
\hline 1998 & 844.1 & +244.0 \\
\hline 1999 & 755.4 & +155.3 \\
\hline 2000 & 710.2 & +110.1 \\
\hline 2001 & 514.2 & -85.86 \\
\hline 2002 & 730.0 & +129.9 \\
\hline 2003 & 706.7 & +106.6 \\
\hline 2004 & 648.1 & +48.04 \\
\hline 2005 & 624.3 & +24.24 \\
\hline 2006 & 715.7 & +115.6 \\
\hline 2007 & 631.9 & +31.64 \\
\hline 2008 & 506.4 & -93.66 \\
\hline 2009 & 668.5 & +68.44 \\
\hline Mean & 600.06 & \\
\hline
\end{tabular}

Source: Author's Computation, 2014

\section{Trend in Onset, Cessation and Length of the Growing Season in Sokoto State}

Onset and cessation dates play a significant role in measuring precipitation effectiveness. The overall concentration of the onset dates as indicated in Table 2 shows that June recorded highest with $50 \%$, while July had $20 \%$ and May $30 \%$. However, the Table 2 shows $80 \%$ of cessations are between $1^{\text {st }}$ to $15^{\text {th }}$ September, while $5 \%$ of the cessations were experienced in October and $15 \%$ around August. It can also be conspicuously seen from table 1.2 that the year 1976 had the longest duration of the rainy season with 132 days, 
followed by 125 days in 1981 and 2005. These indicated that there is variability in the annual rain days for the period 1970-2009. The lowest duration of the wet season were recorded in 1974 with only 39 days, 1971 had 64 days and 1970 had 68 days. Variability in rain days and duration could be said to have adversely affect food production and poses danger to food security.

\section{Trend in Dry Spells in Sokoto State}

The rainy season in the Sahel is characterized by a sequence of days without precipitation or very low precipitation known as dry spell. The length of dry spell is the number of days until the next day with rainfall greater than a given threshold value (Sivakumar, 1992). The threshold value of dry spell is considered to be less than $2.5 \mathrm{~mm}$ (Chowdhury, 1978). The analysis of dry spells were examined using five consecutive days without rains or very low rainfall of less than $2.5 \mathrm{~mm}$ between $7^{\text {th }}$ May, (onset date) to $30^{\text {th }}$ September (cessation date). The highest frequency of dry spells was recorded in 1971 with value 16. The frequency decreases to 10 (1972), 9 (1973) and 8 in 1974; while the lowest frequency was recorded in 1998 with value 6 .

Table 2. Rainfall Characteristics in Sokoto State.

\begin{tabular}{|c|c|c|c|c|}
\hline Years & Onset & Cessation & $\begin{array}{c}\text { Duration of } \\
\text { Rainy Season }\end{array}$ & $\begin{array}{c}\text { No. of Rain } \\
\text { Days }\end{array}$ \\
\hline 1970 & $2^{\text {nd }}$ July & $15^{\text {th }}$ September & 74 & 40 \\
\hline 1971 & $9^{\text {th }}$ June & $10^{\text {th }}$ August & 63 & 30 \\
\hline 1972 & $18^{\text {th }}$ May & $8^{\text {th }}$ September & 113 & 38 \\
\hline 1973 & $27^{\text {th }}$ June & $22^{\text {nd }}$ September & 83 & 40 \\
\hline 1974 & $11^{\text {th }}$ July & $8^{\text {th }}$ September & 59 & 52 \\
\hline 1975 & $18^{\text {th }}$ May & $16^{\text {th }}$ September & 121 & 50 \\
\hline 1976 & $23^{\text {rd }}$ May & $2^{\text {nd }}$ October & 132 & 54 \\
\hline 1977 & $4^{\text {th }}$ June & $19^{\text {th }}$ September & 107 & 50 \\
\hline 1978 & $15^{\text {th }}$ June & $8^{\text {th }}$ September & 85 & 44 \\
\hline 1979 & $11^{\text {th }}$ June & $19^{\text {th }}$ September & 101 & 43 \\
\hline 1980 & $23^{\text {rd }}$ May & $2^{\text {nd }}$ August & 72 & 40 \\
\hline 1981 & $19^{\text {th }}$ May & $20^{\text {th }}$ September & 125 & 43 \\
\hline 1982 & $2^{\text {nd }}$ June & $24^{\text {th }}$ September & 85 & 33 \\
\hline 1983 & 1sth June & $23^{\text {rd }}$ September & 115 & 32 \\
\hline 1984 & $24^{\text {th }}$ June & $12^{\text {th }}$ September & 81 & 30 \\
\hline
\end{tabular}




\begin{tabular}{|c|c|c|c|c|}
\hline 1985 & $7^{\text {th }}$ June & $21^{\text {st }}$ September & 107 & 37 \\
\hline 1986 & $3^{\text {rd }}$ July & $12^{\text {th }}$ September & 72 & 32 \\
\hline 1987 & $1^{\text {st }}$ July & $6^{\text {th }}$ September & 68 & 32 \\
\hline 1988 & $14^{\text {th }}$ June & $8^{\text {th }}$ September & 87 & 44 \\
\hline 1989 & $6^{\text {th }}$ June & $17^{\text {th }}$ September & 104 & 53 \\
\hline 1990 & $30^{\text {th }}$ May & $22^{\text {nd }}$ September & 116 & 42 \\
\hline 1991 & $8^{\text {th }}$ May & $2^{\text {nd }}$ August & 87 & 57 \\
\hline 1992 & $6^{\text {th }}$ June & $9^{\text {th }}$ September & 96 & 41 \\
\hline 1993 & $26^{\text {th }}$ May & $15^{\text {th }}$ September & 113 & 42 \\
\hline 1994 & $29^{\text {th }}$ June & $8^{\text {th }}$ September & 72 & 49 \\
\hline 1995 & $4^{\text {th }}$ July & $16^{\text {th }}$ September & 75 & 47 \\
\hline 1996 & $24^{\text {th }}$ May & $17^{\text {th }}$ September & 117 & 45 \\
\hline 1997 & $11^{\text {th }}$ May & $2^{\text {nd }}$ August & 84 & 50 \\
\hline 1998 & $16^{\text {th }}$ June & $4^{\text {th }}$ September & 81 & 52 \\
\hline 1999 & $2^{\text {nd }}$ July & $5^{\text {th }}$ September & 66 & 58 \\
\hline 2000 & $11^{\text {th }}$ June & $1^{\text {st }}$ September & 83 & 41 \\
\hline 2001 & $2^{\text {nd }}$ July & $22^{\text {nd }}$ September & 83 & 41 \\
\hline 2002 & $2^{\text {nd }}$ June & $4^{\text {th }}$ September & 95 & 48 \\
\hline 2003 & $18^{\text {th }}$ June & $1^{\text {st }}$ August & 45 & 37 \\
\hline 2004 & $7^{\text {th }}$ May & $1^{\text {st }}$ August & 87 & 45 \\
\hline 2005 & $11^{\text {th }}$ May & $12^{\text {th }}$ September & 125 & 43 \\
\hline 2006 & $2^{\text {nd }}$ July & $3^{\text {rd }}$ September & 64 & 51 \\
\hline 2007 & $2^{\text {nd }}$ June & $15^{\text {th }}$ September & 106 & 47 \\
\hline 2008 & $3^{\text {rd }}$ June & $16^{\text {th }}$ September & 106 & 47 \\
\hline 2009 & $2^{\text {nd }}$ June & $15^{\text {th }}$ October & 104 & 43 \\
\hline
\end{tabular}

Source: Author's Computation, 2014. 
Table 3. Comparison between SPI and RAI.

\begin{tabular}{|c|c|c|c|}
\hline Years & SP1 & + RAI & -RAI \\
\hline 1970 & 0.15 & 0.52 & 0.47 \\
\hline 1971 & -1.50 & -5.21 & -4.72 \\
\hline 1972 & -0.38 & -1.33 & -1.21 \\
\hline 1973 & 1.57 & -5.47 & -4.95 \\
\hline 1974 & 0.70 & -2.45 & -2.21 \\
\hline 1975 & -0.34 & -1.17 & -1.06 \\
\hline 1976 & 0.43 & 1.51 & 1.37 \\
\hline 1977 & 1.37 & 4.78 & 4.32 \\
\hline 1978 & 0.65 & 2.26 & 2.04 \\
\hline 1979 & -0.03 & -0.10 & -0.09 \\
\hline 1980 & 0.29 & -0.87 & -0.92 \\
\hline 1981 & 0.23 & -1.02 & -0.72 \\
\hline 1982 & -0.20 & -0.69 & -0.63 \\
\hline 1983 & 0.13 & -0.47 & 0.42 \\
\hline 1984 & -0.94 & -2.26 & -3.03 \\
\hline 1985 & -0.96 & -3.35 & -2.28 \\
\hline 1986 & -0.72 & -2.52 & -4.22 \\
\hline 1987 & -0.34 & -4.67 & -4.22 \\
\hline 1988 & 0.39 & 1.36 & -1.23 \\
\hline 1989 & -0.71 & -2.46 & -2.23 \\
\hline 1990 & 0.31 & 1.08 & 0.99 \\
\hline 1991 & 0.63 & 2.20 & 1.99 \\
\hline 1992 & -0.30 & -1.03 & -0.93 \\
\hline 1993 & 0.25 & 0.84 & 0.77 \\
\hline 1994 & 0.94 & 3.29 & -1.68 \\
\hline 1995 & -0.53 & 1.86 & 2.97 \\
\hline
\end{tabular}




\begin{tabular}{|l|l|l|l|}
\hline 1996 & 0.24 & 0.83 & 0.74 \\
\hline 1997 & 0.26 & 0.92 & 0.83 \\
\hline 1998 & 1.42 & 4.95 & 4.48 \\
\hline 1999 & 0.90 & 3.15 & 2.85 \\
\hline 2000 & 0.64 & 2.23 & 2.02 \\
\hline 2001 & -0.50 & -1.74 & -1.57 \\
\hline 2002 & 0.76 & 2.63 & 2.38 \\
\hline 2003 & 0.62 & 2.16 & 1.96 \\
\hline 2004 & 0.28 & 0.97 & 0.88 \\
\hline 2005 & 0.14 & 0.49 & 0.44 \\
\hline 2006 & 0.67 & 2.34 & 2.12 \\
\hline 2007 & 0.19 & 0.65 & 0.58 \\
\hline 2008 & 0.54 & -1.21 & -1.72 \\
\hline 2009 & 0.40 & 1.35 & 1.26 \\
\hline
\end{tabular}

\section{CONCLUSION}

This paper has critically analysed the meteorological drought in Sokoto State for the past four decades (1970-2009) and the result shows that there is strong seasonal concentration of rainfall in the months of June, July, August and September. Minimum amount were received in the months of May, April and October; while March, November, January and February were virtually very dry months receiving no rainfall except in few cases. Also, between 1971-1975, there was an evidence of meteorological drought as well as dry spell increase, where severe meteorological drought was experienced. In addition, temporal analysis of SP1 shows that different drought scenarios were emerged. These include mild, moderate and severe drought. Finally, the SP1 and RA1 as two meteorological indices show a strong relationship between them at $99.2 \%$ significance level.

\section{Recommendations}

The paper recommends the followings:

1) There is need to develop strategies for drought preparedness and its mitigation for both short and long terms.

2) Meteorological based indicator of drought should be complemented with satellite based indicator. This can assist in advance early warning of drought.

3) Rainwater harvesting technology should be developed across the state such that during period of heavy rainfall the excess rain could be harvested and stored for use during period of dry spells and drought. 
4) There should be effective communication with farmers concerning the appropriate dates of onset and cessation so as to enhance crop and food production in the state.

5) Further studies should be encouraged on the impact assessment of meteorological drought in the study area.

\section{References}

[1] Akeh L.E., Nnoli N., Gbuyiro S., Ikehua F., Ogunbo S. (1999). Meteorological Early Warning System (EWS) for Drought Preparedness and Drought Management in Nigeria, Nigerian Meteorological Services Nigeria.

[2] Ayoade J.O. (2004). An Introduction to Climatology for the Tropics. Ibadan University Press, Ibadan.

[3] Bhalme J.N., Mooley D.A. (1980). Large Scale Flood and Monsoon Circulation.

[4] Bruins H.J., Berliner P.R. (1998). Bioclimatic Aridity. Climatic Variability, drought and desertification, Definition and Management option. Kluwer academic publisher, Dordrecht, pp. 97-116.

[5] Chowdhury H., International Journal of Climatology 17 (1978) 123-130.

[6] Fidelis C.O. (2003). Studies on Drought in Sub-Saharan Region of Nigeria using Remote Sensing and Precipitation. Department of Geography, University of Lagos, Nigeria.

[7] Gonzalez A. Calle F.A. Casanava J.L. Romo H.C. (2001). Drought Monitoring in Spain using Remote Sensing Technique during the period of 1987-2000. Remote sensing laboratory. C. FOR-IWA Madrid Spain. Source: www.gisdevelopment.com, Retrieved on 12-08-2013.

[8] ISDR (2003). Drought Discussion Group, Drought living with Risk. An Integrated Approach to Reducing Societal Vulnerability to Drought. Secretariat for International Strategy for Disaster Reduction. Geneva, Switzerland.

[9] Jesslyn F.B., Bradley C.R., Michael J.H., Donald A., Whilhite K.H., Journal of Climatology 11 (2002) 177-204.

[10] NIMET (2011). Seasonal Rainfall Prediction and its Socio-Economic Implications in Nigeria. Annual Publication of Nigerian Meteorological Agency.

[11] National Population Commission, (2006). National Population Census and Demographic Data.

[12] Odekunle T.O., Journal of Climatology 24(4) (2004) 731-742.

[13] Otun J.A., Adewumi J.K. (2009). Drought Quantification in Semi-Arid Region using Precipitation Effective Variables. Department of Water Resources and Engineering, Ahmadu Bello University Zaria, Nigeria.

[14] Rooy-van M.P., Independent of Time and Notos. 14 (1965) 43-48.

[15] Sinha-Ray K.C. (2001). Role of Drought Early Warming System for Sustainable Agricultural Research in India. India Meteorological Department, Pune, India.

[16] Sivakumar M.V.K., Journal of Climatology 5(5) (1992) 535-539. 
[17] Smakhtin V.V., Hughes D.A. (2004). Automated Estimation and Analysis of Drought Indices, South Asia. Working paper 83 Colombo, Sri Lanka; International Water Management Institute.

[18] Walter W.M., Nig. Geographical Journal 1 (1967) 128.

[19] WMO (2006). Drought Monitoring and Early Warning, Concepts, Progress and Future Challenges. Weather and Climate Information for Sustainable Agricultural Development. 